BENM 2021

International Scientific and Practical Conference "Biotechnology, Ecology, Nature Management"

\title{
INFLUENCE OF CHELATED MINERAL SUPPLEMENT ON RABBIT PRODUCTIVITY
}

\author{
Natalia A. Golovacheva (a)*, Yulia V. Tolmacheva (b), Anastasia A. Klimuk (c), \\ Evgenia V. Korenduhina (d) \\ *Corresponding author
}

(a) K.G. Razumovsky Moscow State University of Technologies and Management (the First Cossack University), 73, Zemlyanoy Val str., Moscow, Russia,n.a.golovacheva@inbox.ru

(b) K.G. Razumovsky Moscow State University of Technologies and Management (the First Cossack University), 73, Zemlyanoy Val str., Moscow, Russia, y.tolmacheva@mgutm.ru

(c) K.G. Razumovsky Moscow State University of Technologies and Management (the First Cossack University), 73, Zemlyanoy Val str., Moscow, Russia, klimukanastasia27@gmail.com

(d) K.G. Razumovsky Moscow State University of Technologies and Management (the First Cossack University), 73, Zemlyanoy Val str., Moscow, Russia

\begin{abstract}
The article presents the results of experiments conducted on rabbits of the California breed. The aim of the research was to study the growth and development indicators of rabbits when introducing an organomineral complex into the diet. After studying the dynamics of the live weight of rabbits and evaluating the growth rate while taking the drug, a positive effect was established. The best results were observed in the experimental group, where chelated forms of trace elements were added to the diet of animals at a dose of $0.4 \mathrm{ml} / \mathrm{head}$. In this group, the average weight of one rabbit was $3,216.68 \pm 65.20 \mathrm{~g}$, which is $7.11 \%$ more than in the control group. The absolute increase in live weight was $522.56 \pm 27.78 \mathrm{~g}$, which is $3.36 \%$ more than in control animals. The average daily growth margin was $3.34 \%$. Such indicators are explained by the positive effect of the organo-mineral complex on the development and general physiological state of the body of young rabbits, good feedability and assimilation of feed, normalization of energy metabolism, prevents mineral insufficiency, improves metabolism, accelerates the dynamics of average daily gains and ultimately increases the productivity of animals.
\end{abstract}

2672-8575 (C) 2022 Published by European Publisher.

Keywords: Absolute gain, average daily gain, chelated forms of trace elements, live weight, organo-mineral supplement 


\section{Introduction}

An important task of agriculture is to increase the production of high-quality livestock products (Komlackij et al., 2013). The development of rabbit breeding in the Russian Federation is given great attention as one of the sources of supply of the population with dietary meat and valuable fur (Balakirev \& Kalugin, 2015; Plotnikov, 2003). In addition, rabbits are a good biological object for scientific experiments (Bublik et al., 2003).

Nowdays, the issues of keeping, breeding and feeding rabbits have been well studied (Golovacheva, Bychkova et al., 2020; Golovacheva, Kozlov et al., 2020; Karabanova \& Efremov, 2012). It is well known, that health, productivity and reproduction of animals depend on the level of feeding (Kalashnikov \& Fisin, 2003). Any high-quality food has a sufficient amount of organic and mineral compounds and it is necessary for the processes of metabolism (Golohvast, 2010). However, most often, one feed is not enough to meet the energy and nutrient needs of rabbits (Balakirev \& Kalugin, 2015). Various feed additives are used for this purpose (Balakirev \& Kalugin, 2015; Bublik et al., 2003; Golovacheva, Bychkova et al., 2020; Golovacheva, Kozlov et al., 2020).

Minerals play an important role in the life of living organisms. Along with organic substances, minerals are part of organs and tissues (Bahta et al., 2019). The influence of minerals on the metabolic processes and productivity of animals was established (Bublik et al., 2003; Golovacheva, NikiforovNikishin et al., 2019).

\section{Problem Statement}

In recent years, chelated forms of trace elements in combination with amino acids have been used to intensify production and complete the flow of physiological processes in the body of animals. As a rule, these forms are highly soluble, easily dosed directly into feed, water or milk. This chelated form prevents the loss of trace elements as a result of hydrolysis in the gastrointestinal tract, while antagonism is established between a number of trace elements, vitamin oxidation is prevented, and trace elements are integrated into the metabolic processes in the body (Bahta et al., 2019; Golohvast, 2010).

Feed organomineral additives in the form of chelates have proven themselves well in animal husbandry, poultry and fish farming (Bahta et al., 2019; Simakov et al., 2020). However, the study of the effect of mineral additives in the system of full-fledged animal feeding remains very relevant today.

\section{Research Questions}

The object of the study was rabbits of the California breed kept in the vivarium of the Department of Biology and Ichthyology of Moscow State University of Technology and Management named after K. G. Razumovsky, and the subject of the study was to determine the effectiveness of the mineral supplement influence on the dynamics of live weight and average daily growth of young rabbits. 


\section{Purpose of the Study}

In this regard, the aim of the research was to study the growth and development indicators of rabbits when introducing an organo-mineral complex into the diet. At the same time, the analysis of the dynamics of the live weight of rabbits was carried out and the growth intensity was evaluated in connection with taking the product.

\section{Research Methods}

Scientific studies on the effectiveness of the organo-mineral complex for rabbits were conducted according to the general scheme presented in Table 1.

For the experiments, 32 heads of California rabbits aged 59-61 days were selected, of which 2 groups were formed according to the principle of analog pairs: 1 control $(n=16)$ and 1 experimental $(\mathrm{n}=16)$. The rabbits were kept in cages with 2 heads each.

Table 1. Scheme of experiments to determine the effectiveness of the use of organo-mineral complex in the diet of rabbits of the California breed

\begin{tabular}{|c|c|c|c|c|c|}
\hline \multirow[b]{2}{*}{ Rabbits $(n=16)$} & \multirow{2}{*}{$\begin{array}{c}\text { At the beginning } \\
\text { of the study }\end{array}$} & \multirow[b]{2}{*}{ Feeding ration } & \multicolumn{3}{|c|}{ Research methods } \\
\hline & & & $\begin{array}{c}\text { After } 10 \\
\text { days }\end{array}$ & $\begin{array}{c}\text { After } 22 \\
\text { days }\end{array}$ & $\begin{array}{c}\text { After } 34 \\
\text { days }\end{array}$ \\
\hline Control group & \multirow[b]{2}{*}{ Weigh-in } & Basic diet (BD) & \multirow{2}{*}{\multicolumn{3}{|c|}{$\begin{array}{c}\text { Weigh-in } \\
\text { (determination of the dynamics of live } \\
\text { weight) }\end{array}$}} \\
\hline $\begin{array}{l}\text { Experimental } \\
\text { group }\end{array}$ & & $\mathrm{BD}+\mathrm{OMS}$ & & & \\
\hline
\end{tabular}

To obtain objective and reliable results, all zootechnical norms for feeding and keeping rabbits of both groups were observed. The content and basic diet of all rabbits during the entire study period were the same. For the rabbits of the experimental group, the organo-mineral supplement "Helavit" was added to the main diet in water for 1 month at a dosage of $0.4 \mathrm{ml} /$ head per day. Rabbits of the control group ate only the basic diet without the addition of a mineral supplement. During the experiments, rabbits in all groups had free access to water.

To determine the live weight gains, the experimental livestock was weighed at the beginning of the experiments, as well as on the 10th, 22nd, and 34th days.

The results of the research were subjected to mathematical processing on a personal computer using the Microsoft Excel program with the calculation of arithmetic averages(M), their average statistical errors (m) and the confidence criterion (p), digital data were evaluated using the Student's criterion. In the tables, the information is presented in the form of $\mathrm{M} \pm \mathrm{m}$.

\section{Findings}

Studying the increments of live weight, it was noticed that throughout the entire period of the experiments, the rabbits of both groups evenly added live weight, without any abrupt changes, both in the larger and in the smaller direction. 
However, at the age of 82 days, the rabbits of the experimental group began to exceed their counterparts from the control group in live weight by $155.69 \mathrm{~g}$, which is $6.13 \%$ more. The data is presented in table 2 .

Table 2. Dynamics of live weight of rabbits, $g(n=16)$

\begin{tabular}{ccc}
\hline \multirow{2}{*}{ Age of rabbits, days } & \multicolumn{2}{c}{ Animal groups } \\
\cline { 2 - 3 } & Control & Experienced \\
\hline 60 & $1688,12 \pm 42,68$ & $1656,31 \pm 37,62$ \\
70 & $2198,68 \pm 50,09$ & $2199,25 \pm 62,42$ \\
94 & $2538,43 \pm 75,59$ & $2694,12 \pm 49,46$ \\
& $3003,13 \pm 66,30$ & $3216,68 \pm 65,20$ \\
\hline
\end{tabular}

Notes: $* \mathrm{P} \geq 0,95$

Naturally, the best results were observed in the experimental group, where the organo-mineral supplement was added to the diet at a dose of $0.4 \mathrm{ml} /$ head. per day. In this group, a positive effect of the supplement on the dynamics of live weight was observed. Here, the superiority over the control group was $7.11 \%$.

According to the dynamics of absolute gains, the experimental group was also significantly better (Figure 1).

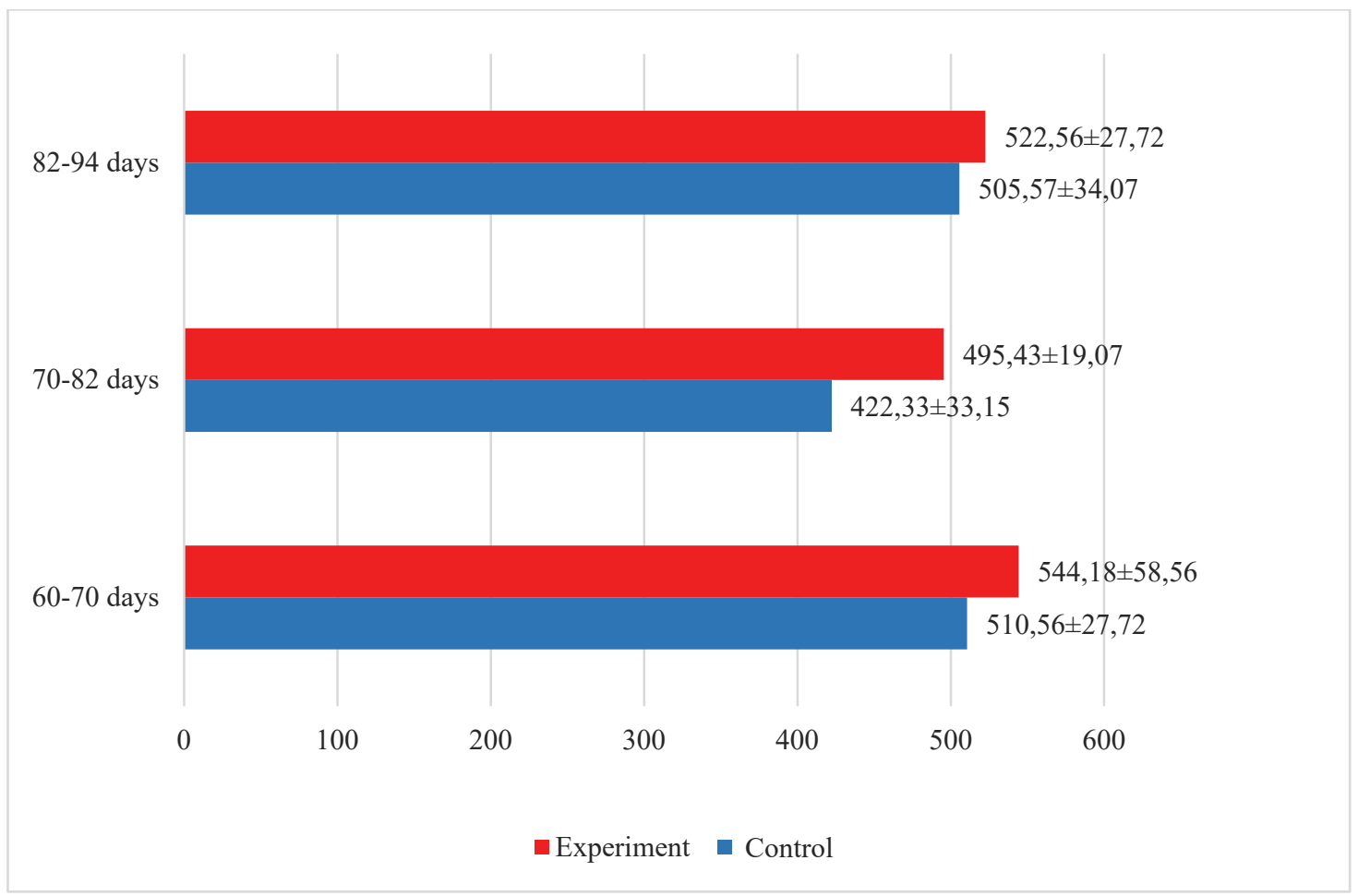

Figure 1. Dynamics of absolute gains of rabbits, $g$

It should be noted that the absolute gains in body weight gradually increased in both groups. So, in the control group for the first 10 days of experiments, the increase was $510.56 \pm 27.72 \mathrm{~g}$, while in the experimental group $-544.18 \pm 58.56 \mathrm{~g}$. 
In the last 12 days of the experiment, the difference in body weight gain was more significant. In the experimental groups, it was $522.56 \pm 27.78 \mathrm{~g}$, and in the control group, $505.57 \pm 34.07 \mathrm{~g}$, which is $3.36 \%$ more.

The average daily gains in live weight of rabbits were calculated from the indicators of absolute gains (Figure 2).

The average daily gains of the control group, in which the rabbits did not receive a mineral supplement, were slightly lower than in the experimental group. By the end of the studies, the difference in the average daily gains in the experimental rabbits compared to the control was 1.41 grams, which is $3.34 \%$ more than in the control.

The analysis of the generalized results of the scientific experiment as a whole is presented in Table 3.

The average live weight of rabbits at the beginning of the experiment in both groups was approximately the same and ranged from 1,656. $31 \pm 37.62$ to $1,688.12 \pm 42.68 \mathrm{~g}$. At the end of the experiments, after 34 days, the live weight of one head was already more than three kilograms. So, in the experimental group, this indicator averaged 3,216. 68 $\pm 65.20 \mathrm{~g}(\mathrm{P} \geq 0.95)$, which is $7.11 \%$ more than their counterparts from the control group.

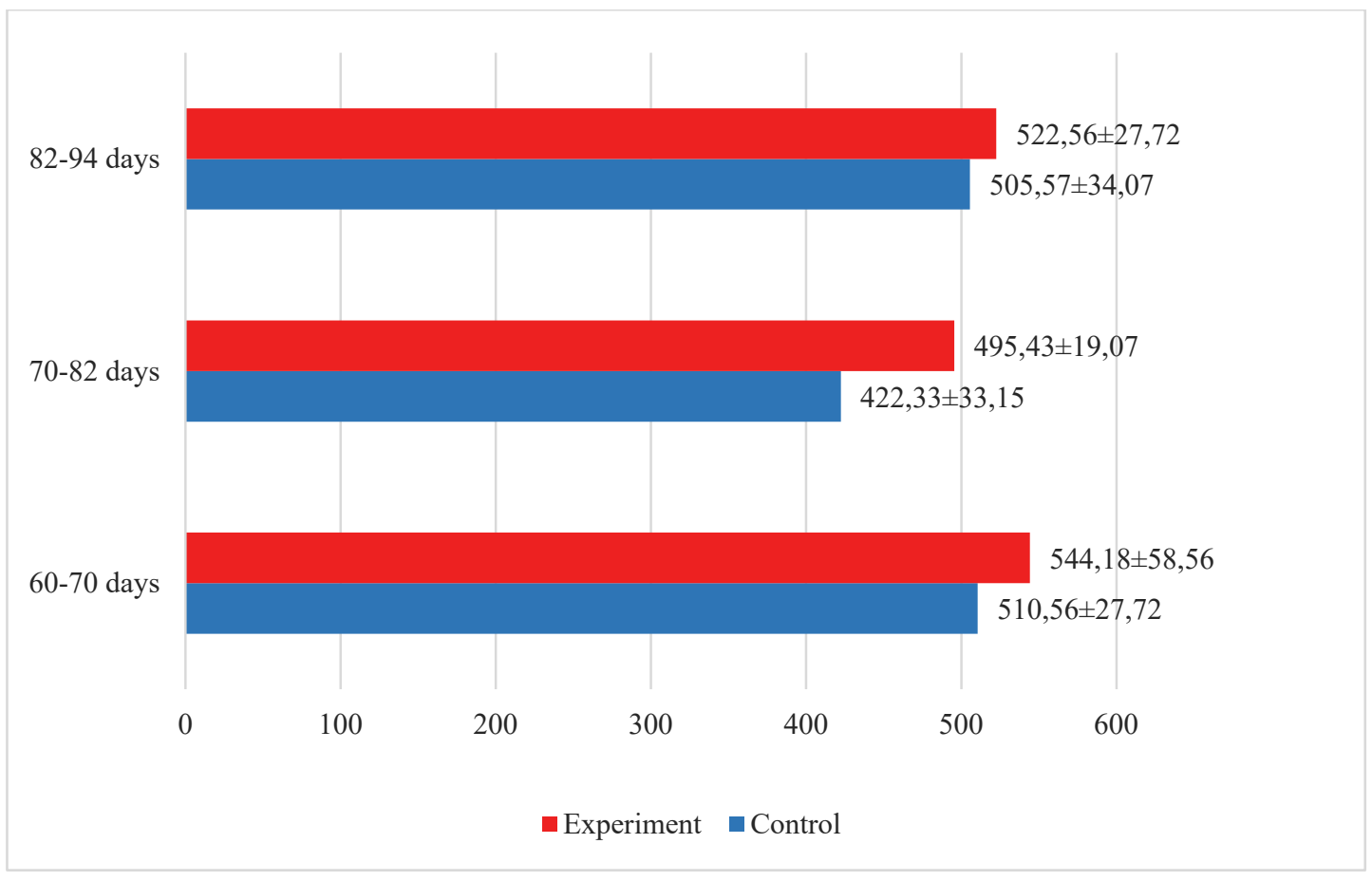

Figure 2. Dynamics of average daily gains of rabbits, $g$

The inclusion of a mineral supplement in the diet in the amount of $0.4 \mathrm{ml} /$ head. per day, it contributed to an absolute increase in live weight of $522.56 \pm 27.78 \mathrm{~g}$, which is 16.99 grams or $3.36 \%$ more than in rabbits of the control group. The superiority in the average daily increase was $4.41 \mathrm{~g}$. 
Table 3. Generalized results of changes in the live weight of rabbits under the influence of an organomineral supplement $(\mathrm{n}=16)$

\begin{tabular}{ccc}
\hline Indicators & \multicolumn{2}{c}{ Animal groups } \\
\cline { 2 - 3 } & Control & Experienced \\
\hline Live weight of 1 head, g: & $1688,12 \pm 42,68$ & $1656,31 \pm 37,62$ \\
- at the beginning of the experience & $3003,13 \pm 66,30$ & $3216,68 \pm 65,20^{*}$ \\
- at the end of the experience & $505,57 \pm 34,07$ & $522,56 \pm 27,78$ \\
Absolute increase, $\mathrm{g}$ & 100 & 103,36 \\
In \% of the control & $42,13 \pm 3,12$ & $43,54 \pm 2,16^{*}$ \\
Average daily growth, $\mathrm{g}$ & 100 & 103,34 \\
In \% of the control In \% of the control & &
\end{tabular}

\section{Conclusion}

Such indicators are explained by the positive effect of the organomineral supplement on the growth, development and general physiological state of the body of young rabbits, good feed consumption and normalization of energy metabolism. Our data are consistent with the recommendations of scientists on the use of chelated compounds in animal feeding schemes. These compounds normalize the metabolism in the shortest possible time, have a higher antioxidant and immunoprotective activity compared to other widely used drugs (Bahta et al., 2019).

Thus, chelated forms of trace elements contribute to the optimal growth and development of young rabbits. The best results were observed when an organo-mineral supplement was added to the animals ' diet at a dose of $0.4 \mathrm{ml} /$ head. per day, where the absolute increase in live weight of rabbits was $522.56 \pm 27.78 \mathrm{~g}$, which is $3.36 \%$ more than in control animals.

\section{References}

Bahta, A. A., Voronin, M., Enukashvili, A. I., Karpenko, L. Y., Kozlov, Y. M., Starcev, R. V., \& Fedorova, E. M. (2019). Primenenie Helavita v zhivotnovodstve. Sbornik nauchneyh statej $i$ publikacij. Mineral'naya kormovaya dobavka Helavit [Application of Helavit in animal husbandry. Collection of scientific articles and publications. Mineral feed additive Helavit] Tver'.

Balakirev, N. A., \& Kalugin, Y. A. (2015). Krolikovodstvo -perspektivnaya otrasl' zhivotnovodstva [Rabbit breeding is a promising livestock industry] Veterinary, Animal Science and Biotechnology, 7, 20-23.

Bublik, V. N., Simonovich, V. N., Ladysh, I. A., Golovacheva, N. A., \& Krinichnyj, A. N. (2003). Vliyanie prirodnyh mineralov-ceolitov na klinicheskie i biohimicheskie pokazateli krovi krolikov [Influence of natural minerals-zeolites on clinical and biochemical parameters of the blood of rabbits]. Veterinary medicine: Interdepartmental thematic scientific collection, 82, 113-115.

Golohvast, K. S. (2010). Vzaimodejstvie organizmov s mineralami [Interaction of organisms with minerals] DGVTU.

Golovacheva, N. A., Bychkova, L. I., Brezhnev, L. L., Ivanova, Y. S., \& Klimov, V. A. (2020). Study of the effect of feed zeolites supplements of the Kholinsky deposit on hematological parameters of representatives of the Leporidae family. In IOP Conference Series: Earth and Environmental Science (Vol. 421, No. 3, p. 032027). IOP Publishing. https://doi.org/10.1088/1755$1315 / 421 / 3 / 032027$ 
Golovacheva, N. A., Kozlov, A. V., \& Klimov, V. A. (2020). Vliyanie yantarnoj kisloty na dinamiku zhivoj massy krolikov [Influence of succinic acid on the dynamics of the live weight of rabbits]. Bulletin of the Kursk State Agricultural Academy, 5, 117-123.

Golovacheva, N. A., Nikiforov-Nikishin, A. L., Gorbunov, A. V., Kozlov, A. V., Tkachev, A. V., \& Tkacheva, O. L. (2019). Holinskie ceolity v sisteme profilaktiki sal'monelleznoj infekcii zhivotnyh [Choline zeolites in the system for the prevention of Salmonella infection in animals]. Veterinary medicine, 9, 19-22. https://doi.org/10.30896/0042-4846.2019.22.9.19-22

Kalashnikov, A. P., \& Fisin, V. I. (2003). Normy i raciony kormleniya sel'skohozyajstvennyh zhivotnyh [Rates and rations for feeding farm animals]. Koloss.

Karabanova, L. V., \& Efremov, A. P. (2012). Krolikovodstvo i sovremennye tekhnologii ego vedeniya [Rabbit breeding and modern technologies for its management]. Dynamics of systems, mechanisms and machines (Agrobiotechnology), 5, 122-124. https://cyberleninka.ru/article/n/krolikovodstvo-isovremennye-tehnologii-ego-vedeniya

Komlackij, V. I., Loginov, S. V., Komlackij, G. V., \& Ignatenko, Y. A. (2013). Effektivnoe krolikovodstvo: ucheb. posobie [Effective rabbit breeding: textbook. allowanc]. KubGAU.

Plotnikov, V. G. (2003). O tendenciyah razvitiya krolikovodstva v mire [Trends in the development of rabbit breeding in the world]. Rabbit and fur farming, 2, 13-16.

Simakov, G., Nikiforov-Nikishin, A., Nikiforov-Nikishin, D., Beketov, S., Kochetkov, N., \& Klimov, V. (2020). Histological changes in the liver, intestines and kidneys of Clarias gariepinus when using feed with chelated compounds. International Journal of Pharmaceutical Research, 12(03), 312385. https://doi.org/10.31838/ijpr/2020.12.03.331 